\title{
China and the U.S. Comparative Engagement in Africa's Development and Diplomacy
}

\section{Genet Abebaw Asefa ${ }^{1}$, \& Sun Kai ${ }^{1}$}

${ }^{1}$ Ocean University of China, School of International Affairs and Public Administration, Qingdao-Shandong, China.

DOI - http://doi.org/10.37502/IJSMR.2021.4604

\begin{abstract}
Africa is a continent rich in natural resources, young labour, relatively good climatic conditions and a good geographical position for international trade, all of which are vital for development. However, the continent still wallows in high levels of poverty and unequal distribution of resources, socio-economic struggles and political instability resulting in slow development, hence the need for external aid. The problem of Africa has for many years attracted diplomatic relations with major world economies that have seen opportunities to invest in the continent and offer some form of monetary aid. Yet Africa's interactions with these superpowers have varied, some creating mutual benefits while others have been exploitative. This paper reviews the engagement of China and the U.S. in Africa's developmental and diplomatic affairs. It concludes that while the two superpowers have different approaches and interests for Africa, they can achieve more for Africa if they engage together in key developmental and diplomatic areas. Enhanced cooperation and engagement between China, the U.S. and Africa are vital in key areas of, such as public health, politics, security, infrastructure, socioeconomics, as well as the environment.
\end{abstract}

Keywords: Engagement, Investment, Development, Diplomacy, Africa, China, U.S.

\section{Introduction}

The U.S. and China are tangled in a global struggle for influence and power over Africa. Africa has suffered for decades with a myriad of social, political, and economic uncertainties. Dedication and cooperation are essential in eradicating these prevalent problems due to the mix of geographic, socioeconomic challenges, defective institutions, and corrupt, domineering governments. These challenges have been hindering Africa from realizing its full potential in fostering sustainable growth and attaining prosperity. Addressing such challenges will mean many opportunities opening up, especially for youth in entrepreneurship and job creation (Manyuon, 2018). While most of Africa's developmental problems are caused by domestic factors that need local solutions, there is room for external partners to collaborate and to address these challenges for mutual benefit. Most of these external partners, notably China and the U.S., have already established their presence in Africa for many years and are an influential part of the continent's developmental and diplomatic affairs. 


\section{1 | International Journal of Scientific and Management Research 4(6) 40-50}

Africa has been the world's fastest urbanizing region for the past few years. China has placed itself at the forefront of that transformation by providing infrastructural support, while the U.S. has been a major supporter of development assistance including public medical health care services. Notwithstanding numerous powerful countries throughout the world having different goals and partnerships in Africa, the U.S. and China are the biggest players when it comes to influencing the region.

In its initial stages, Chinese investment in Africa had largely been focused on infrastructure development, industry, and access to natural resources (Hanauer and Morris, 2014). However, this investment outlay is becoming more diverse, encompassing both resource-rich states and agricultural exporters, and comprising of external aid, loans, infrastructure investment, commerce, and direct foreign investment. This has been motivated by the diverse range of investment prospects for Chinese enterprises as well as for African economic growth (Kamoche et al., 2021). Furthermore, Chinese investments and loans to many African nations have contributed to a sharp rise in Africa's development and alleviation of poverty on the continent. In the 1990s and the 2000s, the rate of per capita economic growth for Africa increased over three times, going from $0.6 \%$ per year to $2.8 \%$ per year. The improvement of African nations' institutional and macroeconomic frameworks also has contributed to the recent increase in African economic growth (Chen et al., 2015). There has been massive growth in Chinese-African trade since the late 1990s, with annual foreign direct investment rising at a rate of $40 \%$ (Jayaram,et al., 2017). China has thus been the greatest of Africa's trade partners in the last two to three decades.

By contrast, U.S. relations with Africa has been fueled mainly by its concentration on socioeconomic ventures. The U.S. has had a strong bipartisan history of engagement with Africa. This has been aimed at consolidating relations with the continent to respond to health and humanitarian emergencies, indorsing peace and safety, reinforce democracy and noble governance and develop the economy (Cooke, 2013). Global health agendas have had a profound impact on millions of people throughout the African continent, strengthening the continent's public health infrastructure in close collaboration with the Africa Center for Disease Control. Apart from bilateral engagements, the U.S. engages in multilateral assistance programs operated by a variety of international organizations, including the World Bank, the African Development Bank (AfDB), and the International Monetary Fund (IMF) (Cohen and Steiger, 2021). Because Africa's economic development is changing, the U.S-Africa policy in the last few years has also changed from being aid-dependent to becoming trading partners.

The objective of this paper is to review the engagement of China and the U.S. in Africa's developmental and diplomatic affairs. Secondary sources examined include academic publications, trending news and current affairs pertaining to the interests of the two powers in Africa, Africa's main hindrances to development and how the three parties can cooperate to sustainably address African challenges.

\section{Major African Developmental Challenges}

Problems in Africa are real and numerous and they pose obstacles to developmental agendas, like the vision 2030 and the agenda 2063. Despite the varying nature of these problems, they 


\section{2}

International Journal of Scientific and Management Research 4(6) 40-50

need immediate attention, drastic and sustainable measures. Among the main challenges that Africa face, this section highlights the public health crises, corruption, political instability and climate change.

\section{Public Health Crises}

Weak healthcare systems are one of the key developmental challenges for Africa, which has a substantial influence on the continent's economic and social security. Africa has the world's highest underlying problem of prevalent diseases and millions of people die every year due to lack of access to proper medical care. In addition to its unfortunate healthcare systems, Africa has a variety of public health infectious diseases such as cholera, malaria, Ebola, HIV, and lately, the COVID-19 pandemic, as well as a growing load of chronic disorders. Other concerns in Africa, such as poverty, intense conflicts, and government mismanagement, make addressing health issues more difficult.

The advent of the COVID-19 pandemic has even exacerbated the situation by becoming a new challenge for Africa's development. It has so far caused a historic social and economic calamity for not only Africa, but the rest of the world, Many African nations have implemented different measures to fight COVID-19, but instead of ameliorating the situation, these efforts have hurt the lives of the impoverished even more. This is because of the majority of African people are already under shortage of food, economic crisis, and poor infrastructure, so it becomes unbearable for individuals under poverly line to follow the lockdown restrictions. Africa has been one of the worst affected regions in the world hit by the pandemic due to its weak health care systems, prevailing poverty and the high burden of other infectious diseases.

The impacts have had long-term consequences in many areas, including employment, education, food security, the environment, and more. The crisis affects Africa's development by having a major effect on the well-being and on the number of people living in poverty. Africa may expect the first economic recession on the continent in many years because of the disruption caused by the pandemic. Furthermore, the COVID-19 pandemic has caused a debt crisis in Africa that will take years to recover (Moore, 2020) and will need the exclusive cooperation and engagement of many African countries with China and the U.S.

\section{Corruption}

Corruption has been one of Africa's biggest challenges for many years and has had an enormous impact on the continent's economic growth. It has a damaging influence on Africa and other countries of the world, acting as a hindrance to national and regional growth. African countries as a whole have consistently recorded high levels of dishonesty and fraud by several corruption classification institutions (Mike, 2020). In Africa, many corrupt politicians misuse public welfare money for personal gain. Money laundering by public officials from many African countries is a challenge that has been existing for many years. According to Transparency International's anti-corruption directory, many African countries have been stuck in corruption.

Several African countries have worked hard to get rid of corruption and clean up their people and their system. However, these efforts have not yet yielded significant results as corruption 
continues to plague the continent (Duri, 2020). The fight against corruption and its eradication in Africa is the chief obligation of African leaders. However, they have not been doing enough to fight it and advance the continent's development agenda. African countries must therefore combat corruption and prevent it from continuously becoming the primary impediment to the continent's growth and the source of other issues on the continent.

\section{Political instability}

Instability in the political arena over the different periods in several African countries is yet another challenge hindering development in Africa. This has oftentimes resulted in population displacement and successfully caused reduced and unreliable production and productivity to the extent that the collective economy of the continent has remained stunted. Ferocious political crises, civil wars, and inter-communal battles have either broken out or increased in several African countries in the past decade leading to a decrease in the productive and transactional capabilities of the economy. This has exerted hostile pressure on investment and prospective economic growth, creating a flimsy socio-political environment. Political and economic progress are interconnected. There can be no economic growth without a certain level of political stability and economic growth can help stabilize a political system (Dalyop, 2018).

However, the government's existence cannot be guaranteed by economic success or progress alone (Uisoon, 1997). For instance, according to the International Monetary Fund and World Bank (2018) report, Ethiopia was listed as one of the world's fastest-expanding economies (Kisika, 2019) but the country has been on the verge of rising civil war recently necessitated by Political Instability and has disrupted the entire economic activities of the country. Ethiopia suffers many impediments, including ethnic violence and a slow pace of development (eiu.com, 2021). In the short term, heightened security concerns will limit foreign investment and hinder growth.

\section{Climate Change}

Climate Change is attracting the attention of the whole world due to its seriousness. This environmental issue has brought about many negative effects which have the potential to completely disrupt plant and human survival if not well handled. Africa, despite contributing very little to the effects of Climate Change, has been one of the most threatened regions around the world, and now the continent has had to focus on combatting the COVID-19 pandemic and its climate issues side by side (Dewar, 2021). Climate Change has been exacerbated by rising temperatures, rising sea levels, altering precipitation patterns, and more extreme weather. In Africa, this has resulted in increased threats to human health, food and water security, infrastructure investments and socio-economic development, consequently contributing to higher levels of life-threatening poverty.

Furthermore, since the African economy is mostly driven by agriculture, it has been hugely disrupted by the effects of Climate Change. In its long-term ambitious plan, Africa Agenda 2063. Africa acknowledges that climate change is one of the greatest hindrances to the continent's development (unfccc.int, 2020). The World Economic Forum (WEF) study reveals that nine of the top 10 nations have locations in sub-Saharan Africa. According to a UN estimate, Accra, Dakar, Durban, and Lagos are among the 10 largest cities at risk from coastal 
cities and have a combined population of more than 1 million. African people and the economy will likely be greatly damaged by rising climate change occurrences, while people will suffer from illnesses brought on by climate change. The number of migrants caused by floods or drought will have to seek resources, such as food, water, and shelter elsewhere impacted (Felaming, 2019).

\section{Africa is an important destination for investment}

Africa is a developing continent with numerous reasons for becoming the next most important hub for global superpowers. These can be categorized as economics, geopolitics, future markets, demographics, security, and even security of the oil line and untapped mineral resources, among other things. The stakes are high in Africa due to the continent's great availability of natural commodities. For instance, Africa is believed to possess $90 \%$ of the global supply of platinum and cobalt, half of the global supply of gold, two-thirds of the global manganese, and $35 \%$ of the global uranium. It also accounts for over $75 \%$ of the world's Colton, a critical mineral used in electrical gadgets such as cell phones (www.unep.org/regions, 2021).Concerning its location, the African continent is strategically located on the western side of Asia and the eastern side of America, with access to both the Atlantic and Indian Oceans. The maritime waterway that is believed to rule future trade around the world is along the coast of Africa. Thus, Africa's geographical position makes it impossible to overlook. Africa is a continent with a population of over one billion people, and there is a rapidly growing consumer market among the young population. Combined consumer and business spending from Africa will reach $\$ 6.7$ trillion by 2030 (Signe, 2018). Africa is massive in comparison to its billionperson population. It contains a huge undeveloped area that could be managed as a production nucleus for agricultural Products and more.

Additionally, most African countries are labelled on the list of the fastest-growing economies making them important destinations for long-term investment. Africa is represented at the United Nations by 54 countries, many of which vote in unison, making Africa a prominent player in international diplomacy (Sany and Sheehy, 2021). Every country is governed by its own set of policies centred on the capacity for social, economic, political, and security purpose.

\section{China's main interest in Africa}

China has already made significant investments in various emerging Asian countries, as well as in South American countries. For political and economic reasons, African economies are another sensible choice for taking advantage of good developmental potential. In multilateral institutions such as the United Nations, China seeks Africa's backing for its "One China" policy and foreign policy ambitions. In relation with Africa, China primarily pursues three national interests (Sun, 2014): Economically, Africa is primarily viewed as a source of natural resources and commercial prospects for China's domestic expansion. China is politically driven to invest in Africa because it sees the region as a key chance to increase its global footprint and influence. Its political intentions are shown in part by its investments in Africa's infrastructure, as seen by financing provided through the China-Africa Development Fund. The increasing number of Chinese business interests in Africa has created new security issues for China. Recent political instability and crimes in the region have threatened Chinese investments and personnel in ways 
that make the situation worse. China is trying to grow its influence and increase its military footprint in Africa. Chinese military engagement in Africa has expanded significantly over the last few years, going from peacekeeping to multilateral counter-piracy actions in the Gulf of Aden (Russel and Berger, 2020). Most notably in 2017, China built and opened its first formal overseas military base in Djibouti.

\section{The U.S.'s main interest in Africa}

The U.S.'s interest in Africa over the last decade has mostly been focused on counter-terrorism operations against groups like al-Shabab in East Africa and Boko Haram in West Africa. The U.S. has long been the world's most generous contributor to UN peacekeeping operations, the majority of which are based in the African continent. For decades, the US has trained, equipped, and exercised African militaries in order to increase professionalism and capacity, while also developing long-term alliances (Devermont and Steadman, 2020). The U.S. military's strategic priorities in Africa include counter-terrorism, security, stability, global health and the promotion of democracy (Wilkins, 2020). Because its economy is so large, the U.S. has higher Foreign Direct Investment (FDI) outflows than any other country in the world. Trade relations with the continent have promoted trade, investment, and the growing middle class in Africa since. However, the U.S. trade and investment in Africa have declined significantly over the past decade, now accounting for less than $1.5 \%$ of global trade and less than $1 \%$ of FDI (Cook and Williams, 2020). The other set of interests derives from a values-based agenda that emphasizes on democracy and human rights, poverty alleviation, a responses to humanitarian crises (Cooke, 2013).

\section{China surpassing the US influence in Africa}

China has surpassed the United States in terms of diplomatic and commercial connections with Africa. China is already the continent's top trading partner and lender on a bilateral basis. Next to France, China is where most African students are studying abroad. It has become the creditor to about two-thirds of the countries eligible for the G20's debt relief initiative. The majority of African countries that are in debt to China will eventually negotiate a suspension of payments and an extension of the loan payback time, thus strengthening their relations to China and retaining Chinese influence in Africa. China has surpassed the U.S. as the single largest source of FDI into Africa. In 2016, jobs created by Chinese FDI projects reached an all-time high, more than doubling the number created in 2015 and exceeding three times the number created by the next largest investor, the U.S (Moore, 2020, www.africanews.com, 2017).

The U.S. has lagged behind China. Although the Trump administration announced a US-Africa strategy that raised expectations in the African policy community, but failure to engage at a sufficient level have damaged what could have been a major achievement in US-Africa relations (Signe, 2021).

Africa was wracked by wars, epidemics, and foreign debt in the 1990s, resulting in a slew of humanitarian crises. As a result, western countries viewed Africa exclusively through the lens of developmental aid. For example, the European Union's policy toward Africa is determined by immigration issues, specifically on how to prevent Africans from moving to Europe. Furthermore, the new US policy toward Africa appears to be motivated by the need for the US 
to respond to what China is doing in Africa rather than by what Africa requires (Moore, 2020). The Chinese approach to Africa differs significantly from that of the West, despite the fact that it is commonly assumed to only comprise of loans and investments. However, there is something more intriguing about China. For example, over the last 40 years, China has done what no other country has done before, raising close to 800 million of its people out of extreme poverty, setting up the best example for Africa, where poverty remains acute. China brings Africa important infrastructure developmental projects that can significantly contribute to Africa's rapid economic development.

Whereas western companies come to Africa, pay royalties and taxes to African governments in exchange for resources, and African governments utilize the money to fund services, infrastructure, and other projects. Chinese enterprises provide infrastructure for resources. When compared to their counterparts in the United States, Chinese enterprises are more suitable as African partners since they offer reduced costs for the completion of projects. China is currently constructing infrastructure to connect African countries and cities, which will facilitate the development of regional value chains.

\section{China at the forefront of Infrastructure Development in Africa}

Limited infrastructure is one of the pressing obstacles to Africa's economic growth and development. The African continent needs an estimated 150 billion dollars in investment. China, since the introduction of the BRI, has been significantly financing major infrastructure projects in Africa. More than $65 \%$ of Chinese developmental financing to the African public centre goes to infrastructure (Cheraghlou, 2021). Africa lacks infrastructure, especially in the form of paved roads and electricity. Africa has approximately 31 kilometres of paved road per 100 square kilometres of land in comparison to 134 kilometres of paved road in other lowincome countries. Because of this lack of infrastructure, in 2017 for instance, Africa's total share of global trade was equal only to South Korea (African Development Bank, 2018).

China has assisted in meeting some of Africa's infrastructural financing needs over the last two decades and is now the single largest financier of African infrastructure. From roads and rails, to ports and power plants, China is financing promising projects that contribute significantly to Africa's economic opportunities. China holds over $20 \%$ of African debt, and in some countries, such as Zambia and Djibouti, it owns more than $50 \%$ of debt. (Kuo, 2020). Africa's recent economic advances have been affected by the COVID-19 pandemic, and slower growth has resulted in factory closures, stalled infrastructure expenditures, and the possibility of destitution for millions throughout the continent. Under these circumstances, it is expected that in the post-pandemic economic recovery, Africa and China will strengthen their cooperation, restructure previous commitments and receive new investment and financing (kamoche et al., 2021).

\section{The U.S. in Africa's social sector}

The U.S.'s engagement with Africa is usually motivated by security reasons. However, the U.S. has had a long history of investing huge sums of money in strengthening health care systems and other social sectors in the continent. The U. S has consistently been a key developmental partner for Africa, providing over $\$ 7$ billion in aid every year. The largest 
portion of the fund goes to health programs, particularly in the area of HIV AIDS prevention and treatment, but there are several other support programs such as education, governance assistance, agriculture and natural resources. Meanwhile, the United States is the world's largest contributor to the World Bank and several UN agencies, like humanitarian relief agencies that work in Africa (Tomas et al, 2020). More than $\$ 100$ billion has been invested in sub-Saharan African nations since 1990s in the health sector. This makes the U.S the largest donor to sub-Saharan Africa and a leading partner in fighting Public Health emergencies such as the COVID-19 pandemic. More than a quarter of a billion dollars in equipment, training, and education have already been donated to the countries fighting the coronavirus. The U.S. will remain in partnership with Africa to help the continent recover from the pandemic crisis. (ge.usembassy.gov).

More than half a billion Africans still live in countries where they do not have access to electricity, which is a major burden to economic growth on the continent. Under President Obama's Power Africa project that began in 2013, the U.S is working with African governments to provide 60 million new households and companies with power by 2030 . To help the youth of Africa better themselves, the U.S. is implementing education and empowerment programs for children and young adults to help them develop their skills and prepare them to be the future generation of African leaders. Agriculture is critical to Africa's economic growth. Agricultural producers account for more than $60 \%$ of Africa's population. However, because changing weather patterns and extreme weather events, such as droughts and heatwaves, have a significant impact on agricultural production, the U.S is participating vulnerability to climate change into USAID Feed the Future and other regional projects to assist farmers in adapting to and mitigating the effects of climate change (Cohen and Steiger, 2021).

\section{Conclusion}

Africa's socio-economic, political, security, environmental and infrastructure challenges cannot be underestimated. There have been several commitments and initiatives made by joint African governments, such as the commitment to vision 2030 and the Africa Agenda 2063, all of which have been aimed to enhance the affluence of the continent. However, Africa's needs for external support in terms of holistic development, FDI and smooth trade agreements especially from China and the U.S. are indispensable in realizing the continent's Sustainable Development Goals. Furthermore, the engagement of China and the U.S. with Africa in key diplomatic areas may be of significant help to all parties despite China and the U.S. having different agendas for Africa. The U.S. and China are the two most diplomatically and economically influential countries in the world, with much influence exerted on Africa's developing countries. While the Chinese have in recent years exerted more influence on Africa's infrastructure development, such as through the Belt and Road Initiative (BRI), U.S. engagement with Africa has mainly focused on the social-economical aspect, with much emphasis on public health and medical care. Engagement with China and the U.S. is often welcomed by African governments, as it provides them with political legitimacy and aids their economic progress. However, since the two superpowers exert different influences, there is a need for Africa to develop a deliberate and conscious educational program on the influence of the two powers to realize its long-term vision, namely, the Agenda 2063 without being 
exploited. Africa needs both China and the U.S. in its strategic development and diplomatic affairs. Nevertheless, it is imperative that China and the U.S. be engaged in dialogue about their investment and assistance policies towards Africa. In order to accomplish common developmental and diplomatic goals, such dialogue must emphasize enhanced cooperation and investment in key thematic areas of public health, politics, security, infrastructure, socioeconomics (including the removal of international trade barriers) and climate change issues.

\section{References}

1) Daniel Athior Atem Manyuon, (2018), Developmental Challenges and Opportunity in Africa https://minds-africa.org/-anddevelopmental-challenges-opportunity-in-africa/

2) Larry Hanauer, Lyle J. Morris ,(2014), Chinese Engagement in Africa, Drives, Reactions and Implications for U.S. Policy https://www.rand.org/pubs/research _reports/RR521.html

3) Ken kamoche, Saileshsingh Gunesse Nana K.Kufuor, (2021), The Africa-China engagement: Contemporary developments and directions for future research https://www.tandfonline.com/ doi/full/10.1080/23322373.2021.1932349

4) Wenjie Chen, David Dollar, and Heiwai Tang 1 August, (2015), Why is China investing in Africa? Evidence from the firm level. https://www.brookings.edu/wpcontent/uploads/ 2016/06/Why-is-China-investing-in-Africa.pdf

5) Kartik Jayaram, Omid Kassiri, and Irene Yuan Sun, (2017 ), “The Closest Look Yet at Chinese Economic Engagement in Africa," https://mckinsey.com/featuredinsights/middle-east-and- africa/the-closest-look-yet-at-chines-economic-engagementin-africa.

6) Jennifer G. Cooke, (2013). U.S. Engagement in Africa https://www.cairn-int.info/ article-E_PE_132_0067--us-engagement-in-africa.htm

7) Cohen, Z \& Steiger, J. (2021). On Africa Day, Celebrating U.S.-Africa Partnership and Cooperation https://www.usglc.org/blog/on-africa-day-celebrating-u-s-africapartnership-and-cooperation/?gclid

8) Gyude Moore ,(2020), "Chinese influence is assured - how should Africa respond”? https://african.business/2020/11/trade-investment/chinese-influence-is-assured-howshould-africa-respond/

9) Okwuagblala Uzochukwu Mike P (2020). Corruption in Africa: Overview, Causes, Effects, and Solutions - HubPages, https://discover.hubpages.com/politics/

10) Duri, J. (2020), Sub-Saharan Africa: Overview of corruption and anti-corruption https://www.u4.no/publications/sub-saharan-africa-overview-of-corruption-and-anticorruption.pdf

11) Gandong Toma Dalyop, (2018), Political instability and economic growth in Africa, International Journal of Economic studies

12) Kwon, Uisoon, (1997),"The Impact of Political Instability on Economic Growth: Evidence from Developing Countries" Master's Theses. 4007. https://scholarworks.wmich.edu/masters theses/4007

13) Sam Kisika ,(2019), yes-ethiopia-fastest-growing-economy-globally-its-all-details 
https://africacheck.org/fact-checks/reports

14) 14)Ethiopia Economy, Politics and GDP Growth Summary, (2021),- The Economist Intelligence Unit https://country.eiu.com/ethiopia

15) Dewar, B. (2021). Why Africa and partners must go up a gear on climate https://www.chathamhouse.org/2021/02/why-africa-and-partners-must-go-gearclimate?gclid

16) Climate Change Is an Increasing Threat to Africa, (2020), https://unfccc.int/news/limate-change-is-an-increasing-threat-to-africa

17) Sean Felaming ,(2019), https://www.weforum.org/agenda/2019/09/ economic-growthsub-saharan-africa-challenges-risks/

18) Our work in Africa | UNEP - UN Environment Programme. Accessed August 05,2021 https://www.unep.org/regions/africa/

19) Landry Signe ,(2018), “Africa's consumer market potential Trends, drivers, opportunities, and strategies" https://www.brookings.edu/ research/Africa's-consumermarket-potential/

20) Sany, J. and Sheehy, T.P. (2021), Sidestepping Great Power Rivalry: U.S.-China Competition in Africa https://www.usip.org/publications/2021/04/ sidestepping-greatpower-rivalry-us-china-competition-Africa

21) Yun Sun, (2014), "Africa in China's Foreign Policy," Brookings https://www.brookings.edu/research/africa-in-chinas-foreign-policy/pdf.

22) Daniel R. Russel and Blake H. Berger, (2020), "Weaponizing the Belt and Road Initiative," Asia Society Policy Institute, http://asiasociety.org/sites/default/files/2020 09 /Weaponizing\%20the\%20Belt\%20and\%20Road\%20Initiative_0.pdf.

23) Judd Devermont and Leanne Erdberg Steadman, (2020), "Defending the U.S. Military Presence in Africa for Reasons beyond Counterterrorism," Lawfare (blog), http://lawfareblog.com /defending-us military-presence-africa-reasons-beyondcounterterrorism.

24) Sam Wilkins, (2020), Does America Need an Africa Strategy? - War on the Rocks https://warontherocks.com/2020/04/

25) Nicolas Cook and Brock R. Williams,(2020), “The Trump Administration's Prosper Africa Initiative," Congressional Research Service, http://fas.org/sgp/crs /row/IF11384.pdf.

26) China Becomes Single Largest Contributor of Africa's FDI-Report,(2017), https://www.africanews.com/2017/05/04/china becomes the single largest contributor of Africa's FDI-report.

27) Landry Signe,(2021), How to Restore U.S. Credibilityin Africa? https://www.scribd.com/article/491904119/How-To-Restore-U-S-Credibility-In-Afric

28) Amin Mohseni-Cheraghlou ,(2021), Development finance in Sub-Saharan Africa: The Chinese model. https://www.atlanticcouncil.org/blogs/development-finance-in-subsaharan-africa-the-chinese-model/

29) African Development Bank, (2018), cumenthttps://www.icafrica.org/fileadmin/dos/Knowledge/GENERAL_INFRA/Africa nEconomicOutlook2018.pdf

30) Mercy A. Kuo, (2020), “COVID-19: The Impact on China-Africa Debt,” Diplomat, 
50 | International Journal of Scientific and Management Research 4(6) 40-50

http://thediplomat.com/2020/06/covid-19-the-impact-on-china-africa-debt.

Tomas F. Husted, Lauren Ploch Blanchard, Alexis Arieff, and Nicholas Cook, (2020), "U.S.

Assistance to Sub-Saharan Africa: An Overview," Congressional Research Service, http://fas.org/sgp/crs/row/R46368.pdf.

32) U.S embassy in Gorgia, (2021), 20 years of aid: America's ongoing support for Africa's public health https://ge.usembassy.gov/20-years-of-aid-americas-ongoing-support-forafricas-public-health-video-july-15/ 